J. Lake Sci. (湖泊科学) , 2015, 27 (1): 94-102

http: //www. jlakes.org. E-mail : jlakes@niglas.ac.cn

(C) 2015 by Journal of Lake Sciences

\title{
湖北长湖水生植物多样性及群落演替”
}

\author{
郝孟䂀, 杨 否, 孔祥虹, 徐轩, 卢 巍, 李中强** \\ (湖北大学资源环境学院,武汉 430062)
}

\begin{abstract}
摘 要: 在 2011 年的调查基础上, 结合已有资料, 研究长湖水生植物多样性、群落特征、水生植被分布现状及水生植物多 样性的动态变化和群落演替规律, 探讨驱动水生植物群落演替的主导因素. 结果显示长湖现有水生植物 95 种, 水生植物 优势群落 12 个. 与 1985 年相比, 长湖水生植物无论是在优势种还是优势群落上均发生了巨大变化, 从原来以沉水植物为 主的优势群落逐步演替为以挺水植物 + 漂浮浮叶植物为优势的水生植物群落. 同时水生植被分布面积急剧缩小, 生物量 显著下降,2011 年全湖水生植被覆盖率仅为 $4.2 \%$, 单位面积平均生物量只有 2001 年的 $10 \%$, 全湖生物总量相比于 2006 年下降了 $88.5 \%$. 分析表明, 大规模围网养殖等人为干扰活动及水体富营养化是致使长湖水生植物多样性显著下降和群 落发生逆向演替的主要原因.
\end{abstract}

关键词: 多样性;群落结构;演替;保护与恢复;长湖;浅水湖泊

\section{Diversity and community succession of macrophytes in Lake Changhu, Hubei Province}

HAO Mengxi, YANG Lei, KONG Xianghong, XU Xuan, LU Wei \& LI Zhongqiang

( School of Resource and Environmental Science, Hubei University, Wuhan 430062, P. R. China)

\begin{abstract}
Based on previous results and data obtained from field investigation in 2011, the distribution of aquatic vegetation, species diversity and its dynamic changes, community characteristics and succession features of Lake Changhu were studied and the primary driving factors of community succession were analysed. Results showed that there were 95 species of aquatic plants and 12 dominant plant associations in Lake Changhu in the year of 2011. Compared with the results of 1985, both dominant species and preponderant associations changed dramatically. Dominant aquatic plant associations gradually varied from submerged macrophytes associations to the emergent and floating macrophytes. Furthermore, vegetation coverage of the whole lake declined dramatically to $4.2 \%$ and the mean biomass per $\mathrm{m}^{2}$ decreased by $88.5 \%$. Our analyses indicated that human disturbances such as large-scale seine farming activities and water eutrophication were main reasons for diversity reduction and adverse succession of Lake Changhu. Keywords: Diversity; community structure; succession; protection and restoration; Lake Changhu; shallow lake
\end{abstract}

水生植物是湖泊生态系统的初级生产者、水体净化者、生态位的营造者, 也是多种水生动物的栖息地和 产卵场所, 对提高湖泊生态系统的生物多样性至关重要 ${ }^{[1]}$. 然而, 不合理的人为干扰使得水生植物资源逐渐 枯竭, 江河筑坝阻断了水生生物的扩散路径, 围湖造田使得湖湾及沿岸带水生植物的生境丧失, 排污人湖使 得水质恶化,过度养殖加剧了湖泊富营养化程度. 这些人为干扰打破了湖泊的自然演替过程, 造成了水生生 物多样性降低、群落结构简单化和湖泊生态系统功能失调, 致使长江中下游一些原来长满水草的湖泊已经 演替成次生裸地 ${ }^{[2-3]}$; 还有一些湖泊生态系统结构简单化、功能失调, 正在由草型湖泊逆向演替为藻型 湖泊 ${ }^{[4-5]}$.

长湖是湖北省第三大湖, 位于荆州市东北郊, 是一个四周全为堤渠的独特湖泊, 兼有生活供水、调蓄、防 洪、渔业、旅游、灌溉、改善生态环境和维持生物多样性等多种功能. 1950s - 1980s 初期, 长湖水生植物多样

* 国家自然科学基金项目(31270261)、国家科技基础性工作专项项目(2013FY112300)和湖北省杰出青年基金项目 (2010CDA098) 联合资助. 2013-12-30 收稿;2014-04-08 收修改稿. 郝孟䂀(1988 ), 女, 硕士研究生; E-mail: 564628214@ qq.com.

** 通信作者;E-mail: lizhq@whu. edu.cn. 
性保存良好,但 1980s 中后期至今, 自然干扰 (干旱、水涝等)的频繁发生及人为干扰 (大规模围网围栏养殖、 围堤建坝、旅游观光和过量使用农业化肥及排放工业生活废水等) 的日益加剧已经严重阻碍了水生植物的 生长繁衍,致使水生植物分布区明显缩小、生物量显著下降,不仅影响了沿湖居民的日常生活和水产业的可 持续发展, 还威胁到长湖湿地的生态安全 ${ }^{[6-7]}$. 因此, 开展长湖水生植物多样性的调查、研究和保护的工作迫 在眉睫.

国内专家学者对长湖水生植物的研究始于 $1980 \mathrm{~s}$, 主要集中在调查水生植物物种、优势种群及分布等方 面 ${ }^{[7-9]}$, 对长湖水生植被长期演变趋势少有研究. 本文通过现场调查, 结合已有的历史资料, 拟研究长湖水生 植物多样性的现状及其长期动态变化特征, 分析水生植物群落演替规律和驱动因子, 为长湖湖泊生态系统 修复和生物多样性保护提供科学合理的参考依据.

\section{1 研究方法}

\section{1 研究区概况}

长湖处于汉江和长江两大主要流域之间, 西邻荆州, 东抵潜江, 北靠荆门,面积达 $131.1 \mathrm{~km}^{2}$, 正常湖容 $5.43 \times 10^{8} \mathrm{~m}^{3}$, 平均水深 $1.7 \mathrm{~m}$, 属于典型的河间洼地型湖泊. 长湖流域在大地构造上属江陵凹陷北缘,地势 西北高,东南低,具有丘陵、岗地、平原等地貌形式 ${ }^{[10]}$. 长湖所处流域属亚热带季风湿润区,四季分明,雨量充 沛, 阳光充足,湖泊水文有缓涨慢落的特征, 且随季节变化明显. 在空间分布上, 长湖水质呈现较强异质性, 不同区域水质差异较大; 在时间尺度上,长湖水质经历了一个良好一恶劣一缓慢恢复的过程. 20 年前长湖水 质较好, 水质等级为 $\mathrm{III}$ 类 ${ }^{[7]}, 2006$ 年水质调查发现长湖水质恶化,大部分水域水质处于 $\mathrm{V} \sim$ 劣 $\mathrm{V}$ 类 ${ }^{[10]}, 2011$ 年湖泊调查发现长湖局部水域水质已恢复到 III 类, 但大部分水域水质仍然较差 (表 1). 目前长湖主要污染包 括工业废水、农村城市生活污水、农业面源污染及精养鱼塘废水污染等 ${ }^{[5-6]}$.

表 1 不同时期长湖水质变化情况

Tab. 1 Water quality of Lake Changhu in different years

\begin{tabular}{|c|c|c|c|c|c|c|c|c|c|}
\hline 时间 & $\begin{array}{c}\text { 透明度/ } \\
\mathrm{m}\end{array}$ & $\begin{array}{l}\text { 溶解氧/ } \\
(\mathrm{mg} / \mathrm{L})\end{array}$ & $\begin{array}{c}\text { 化学需氧量/ } \\
(\mathrm{mg} / \mathrm{L})\end{array}$ & $\mathrm{pH}$ & $\begin{array}{c}\text { 总磷/ } \\
\text { ( mg/L) }\end{array}$ & $\begin{array}{l}\text { 总氮/ } \\
\text { (mg/L) }\end{array}$ & $\begin{array}{l}\text { 氨氮/ } \\
(\mathrm{mg} / \mathrm{L})\end{array}$ & 水质等级 & 富营养状况 \\
\hline 1988 年 & 1.1 & 8.7 & 10.23 & 6.9 & 0.037 & 1.565 & 0.600 & III类 & 中度富营养 \\
\hline 2006 年 & 0.9 & 7.5 & 38.98 & 7.2 & 0.098 & 2.074 & 0.352 & V 劣 V 类 & 富营养 \\
\hline 2011 年 & 0.6 & 8.4 & 5.98 & 7.4 & 0.051 & 0.848 & 0.510 & III $\sim \mathrm{V}$ 类 & 中度富营养 \\
\hline
\end{tabular}

\section{2 水生植物物种多样性研究}

2011 年 9 月对长湖湖岸及湖面水生植物进行采样调查, 调查内容包括水生植物种类、分布面积、多度、 盖度、生物量、优势种、群落结构组成及优势群落等. 该研究根据第 2 次湖北省湿地资源调查划分的调查斑 块,研究采用样地和样方结合法,依据斑块面积大小和斑块生境的复杂程度适当选取调查样带及确定样点 数量,之后用 GPS 按照一定间距均匀布设样方. 调查单元内, 每个植物群落设置样方数量不少于 3 个,平均 高度大于 $2 \mathrm{~m}$ 的植物样方面积设置为 $2 \mathrm{~m} \times 2 \mathrm{~m}$, 平均高度介于 $1 \sim 2 \mathrm{~m}$ 之间的植物样方面积设置为 $1 \mathrm{~m} \times$ $1 \mathrm{~m}$, 平均高度小于 $1 \mathrm{~m}$ 的植物样方面积设置为 $0.5 \mathrm{~m} \times 0.5 \mathrm{~m}$. 采集的水生植物标本由调查人员及专家现场 鉴定所属类别,部分水生植物压制成标本予以保存.

该调查中物种多度采用 Braun-Blanquet 的多度等级划分标准,即 5 代表非常多,4 代表多,3 代表较多,2 代表较少, 1 代表少, + 代表极少.

\section{3 水生植物群落多样性研究}

群丛的命名采用优势种原则, 即以各群丛优势种名称作为该群丛的名称. 优势种的确定采用重要值方 法, 其中重要值 $=($ 相对频度 + 相对盖度 + 相对多度 $) / 3$, 多度、盖度用目估法测定. 同一层次的优势种之间 用“+”连接,不同层次的优势种之间用“ - ”连接.

\section{4 水生植被群落多样性指数及均匀度指数的计算}

根据《中国植被》 ${ }^{[11]}$ “群丛是植被类型最基本的分类单元” 的原理,每个群丛各设 3 个 $1 \mathrm{~m} \times 1 \mathrm{~m}$ 的样 
方, 用于研究群落物种多样性指数, 通过计算 Shannon-Wiener 多样性指数和 Simpson 多样性指数相互验证增 加结果的可信度, 公式分别为 $H=-\sum_{k=1}^{n}\left[P_{k} \ln \left(P_{k}\right)\right]$ 和 $D=1-\sum_{k=1}^{n} P_{k}^{2}$, 其中 $P_{k}$ 为第 $k$ 种的相对重要值.

\section{5 水生植被覆盖率及生物量的计算}

对不同水生植物群落, 采样过程中使用手持 GPS 定位, 记录群落边界坐标, 结合测距仪测定边界长度, 然后用 ArcGIS 软件描绘水生植被图, 求算各群丛的分布面积, 将各群丛植被面积之和除以湖泊总面积即得 全湖水生植被覆盖率.

在湖面测定点位, 用 $50 \mathrm{~cm} \times 50 \mathrm{~cm}$ 采草器随机打草 3 次, 将水生植物尽可能连根夹起, 除去枯枝死叶并 及时冲洗干净进行分类处理, 分别记录湿重取平均值, 以湿重代表生物量, 然后计算单位面积生物量. 对岸 带湿地植物, 在每个采集点随机设置 6 个 $1 \mathrm{~m} \times 1 \mathrm{~m}$ 的样方, 将植物连根拔起, 洗净去除污泥, 称量所有植株 的生物量 (湿重),而后计算单位面积生物量.

\section{6 典范对应 (CCA) 分析法}

CCA 分析方法必须具备两个数据矩阵, 即物种数据矩阵和环境数据矩阵 ${ }^{[12]}$. 本文长湖的物种数据经过 严格篎选, 选取的物种在每个样点分布盖度 $\geqslant 5 \%$, 环境数据剔除误差较大的因子, 保留相关性较好的水深 (D)、透明度 $(\mathrm{SD}) 、 \mathrm{pH}$ 值、总氮 $(\mathrm{TN})$ 、总磷 $(\mathrm{TP}) 、$ 化学需氧量 $(\mathrm{COD})$ 、矿化度 $(\mathrm{Ds}) 、$ 电导率 ( Cond ) 8 个因子. 将 Excel 里的物种数据及环境数据在 WcanoImp 中转化为 CANOCO 4.5 软件可识别的 spe. dta 和 env. dta 文 件, 先对物种数据进行去趋势对应分析 (DCA 分析), 以消除弓形效应, 确定是否适合运用 CCA 分析方法. 应 用 CANOCO for Windows 进行计算,将生成的数据文件 spe-env. cdw 在 Canodraw 中作图, 排序结果用物种一 环境因子关系的双序图表示, 图中环境因子用带箭头的线段表示, 向量在第 $1 、 2$ 轴上的投影长短表示该环 境因子的作用大小, 投影所处象限代表环境因子与排序轴间的正负关系.

\section{2 结果}

\section{1 不同时期长湖水生植物主要优势种的变化}

据 1985 年的调查资料显示 ${ }^{[7]}$, 长湖共有水生维管束植物 40 种, 分属于 20 科, 其中以眼子菜科 ( Potamogetonaceae) 和莎草科 (Cyperaceae) 的种类最多. 该时期主要优势种为菹草 (Potamogeton cripus)、穗花狐尾 藻 (Myriophyllum spicatum) 、金鱼藻 (Ceratophyllum demersum) 和轮叶黑藻 (Hydrilla verticillata). 从多度看, 以 金鱼藻、穗花狐尾藻和菹草的多度最高, 其次是野菱 (Trapa incisa)、密齿苦草( Vallisneria denseserrulata)、轮 叶黑藻、浮萍 (Lemna minor) 和菰 (Zizania latifolia).

2001 年调查 ${ }^{[9,13]}$ 发现长湖水生植物共 34 科 62 属 98 种 3 变种,种类以莎草科、禾本科 (Poaceae) 和蓼科 (Polygonaceae) 为多, 分别为 $15 、 13$ 和 10 种. 该时期主要优势种有密齿苦草、菹草、穗花狐尾藻、金鱼藻、轮叶 黑藻、微齿眼子菜 (P. maackianus)、菱 ( T. bispinosa) 、紫萍 (Spirodela polyrhiza)、满江红 (Azolla mbricata). 从多 度看, 这些水生植物中多度最高的是菱、紫萍、满江红、密齿苦草、轮叶黑藻、微齿眼子菜、菹草, 其次是李氏 禾(Leersia hexandra)、针萄( Eleocharis congesta)、喜早莲子草(Alternanthera philoxeroides)、荆三棱 (Scirpus fluviatilis)、浮萍、半边莲 (Lobelia chinensis) 、大茨藻 (Najas marina) 、小茨藻 ( N. minor)、金鱼藻、穗花狐尾藻和 马来眼子菜 $(P$. malaianus $)$.

2011 年调查发现长湖水生维管束植物物种多样性较高, 共计 46 科 74 属 95 种, 其中挺水植物 31 科 71 种, 漂浮浮叶植物 9 科 14 种,沉水植物 6 科 10 种. 优势种主要包括轮叶黑藻、金鱼藻、菱、水蓼 (Polygonum hydropiper)、菰、狭叶香蒲 (Typha angustifolia) 、喜早莲子草和凤眼莲(Eichhornia crassipes). 从多度看, 多度最 高的是金鱼藻、轮叶黑藻、浮萍、槐叶萍 (Salvinia natans) 、菱和菞, 其次是穗花狐尾藻、满江红、水鳖 ( Hydrocharis dubia)、喜早莲子草、凤眼莲、水蓼和莲 (Nelumbo nucifera).

\section{2 不同时期长湖水生植被群丛类型及优势群丛的变化}

据资料记载, 1985 年 ${ }^{[7]}$ 长湖水生植物群丛类型有 4 大类, 12 个群丛, 其中 3 个挺水植物群丛, 主要是芦 苇群丛 (P. communis association)、菰群丛 (Z. latifolia association) 和菰一荇菜一马来眼子菜群丛 ( Z. latifolia- $N$. peltata-P. malaianus association);3 个浮叶植物群丛, 以荇菜群丛 ( N. peltata association) 和菱群丛 ( $T$. bispi- 
nosa association) 为主; 1 个漂浮植物群丛, 即紫萍群丛 ( S. polyrhiza association);5 个沉水植物群丛, 分别是苦 草群丛( V. natans association)、淔草群丛( P. crispus association)、穗花狐尾藻群丛( M. spicatum association)、 马来眼子菜群丛和金鱼藻 + 轮叶黑藻群丛 $(C$. demersum $+H$. verticillata association). 该时期主要优势群丛 是菹草群丛、穗花狐尾藻群丛、金鱼藻 + 轮叶黑藻群丛、菰一荇菜-马来眼子菜群丛和菰群丛.

2001 年调查发现长湖水生植物群丛 14 个 $^{[9]}$, 其中挺水植物群丛 4 个, 分别是芦苇群丛、荻群丛 ( M. sacchariflorus association)、莲群丛( N. nucifera association) 和荆三棱群丛 (S. fluviatilis association); 浮叶植物群 丛 2 个, 即野菱群丛 ( T. incisa association) 和菱群丛 ( T. bispinosa association); 漂浮植物群丛 3 个, 主要是紫 萍群丛、满江红群丛 (A. imbricata association) 和紫萍 + 满江红 + 苂实群丛 $(S$. polyrhiza + A. imbricata + E. ferox association); 沉水植物群丛 5 个, 为微齿眼子菜群丛 ( P. maackianus association)、穗花狐尾藻群丛、密齿 苦草群丛、蕰草群丛和微齿眼子菜 + 轮叶黑藻 + 大茨藻群丛 $($ P. maackianus $+H$. verticillata $+N$. marina association), 沉水植物群丛为该时期主要的优势群丛.

2011 年实地调查发现长湖共有水生植物群丛 12 个, 其中挺水植物群丛 4 个, 为菰群丛、莲群丛、喜旱莲 子草群丛 (A. philoxeroides association) 和狭叶香蒲群丛 ( T. angustifolia association); 浮叶植物群丛 1 个, 为菱 群丛; 漂浮植物群丛 3 个, 为紫萍 + 满江红群丛 $(A$. imbricata $+S$. polyrhiza association)、凤眼莲群丛( E. crassipes association) 和槐叶萍一金鱼藻群丛 ( $S$. natans-C. demersum association); 沉水植物群丛 4 个, 分别是是密 齿苦草群丛、轮叶黑藻 + 穗花狐尾藻群丛 $(H$. verticillata + M. spicatumassociation $) 、$ 蕰草 + 穗花狐尾藻 + 金 鱼藻群丛 $($ P. crispus + M. spicatum + C. demersum association $)$ 和金鱼藻 + 轮叶黑藻群丛 $($. demersum $+H$. verticillata association). 主要的优势群丛有菹草 + 穗花狐尾藻 + 金鱼藻群丛、密齿苦草群丛、喜旱莲子草群 丛、狭叶香蒲群丛、菰群丛、莲群丛和紫萍 + 满江红群丛. 2011 年长湖水生植物群丛分布情况见图 1.

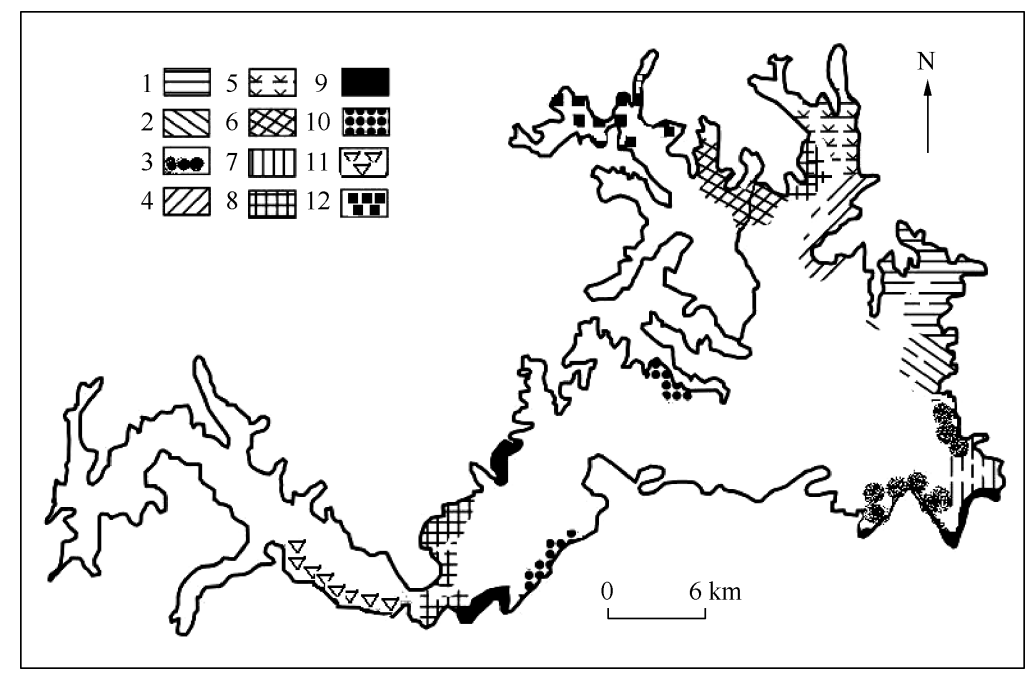

图 12011 年长湖水生植被分布 (1: 轮叶黑藻 + 穗花狐尾藻群丛; 2 : 槐叶萍一金鱼藻群丛; $3:$ 菹草 + 金鱼藻 + 穗花狐尾藻群丛; 4 : 菱群丛; 5 : 金鱼藻 + 轮叶黑藻群丛; 6 : 密齿苦 草群丛;7: 菰群丛; 8 : 喜早莲子草群丛;9: 莲群丛; 10 : 凤眼莲群丛; 11 : 满江红 + 紫萍 群丛; 12 : 狭叶香蒲群丛)

Fig. 1 Aquatic vegetation sketch of Lake Changhu in 2011

\section{3 长湖水生植物群落多样性指数的变化及时空演替}

近几十年来长湖水生植被的群落多样性和分布面积比例发生了较大变化 ${ }^{[13-14]} .1985$ 年占据长湖水生植 物群落面积比例最大的群丛是金鱼藻 + 轮叶黑藻群丛,该群丛面积约占全湖水生植被总面积的 $18.8 \%$, 主 要分布在水深 $1.1 \sim 2.0 \mathrm{~m}$ 的浅水沉水带,植物种类组成比较复杂, 还伴生有密齿苦草、小茨藻和菱等; 其次 是菹草群丛和穗花狐尾藻群丛, 占据的比例分别为 $15.8 \%$ 和 $15.0 \%$, 这两个群丛多分布于 $0.9 \sim 2.8 \mathrm{~m}$ 的水 
域内, 常伴生有轮叶黑藻、密齿苦草和小茨藻等; 全湖分布面积最小的是荇菜-菹草 + 穗花狐尾藻群丛, 主要 分布在水深 $0.3 \mathrm{~m}$ 的岸边浅水区,伴生种有金鱼藻和轮叶黑藻 (表 2).

表 2 不同时期长湖水生植物群落多样性*

Tab. 2 Community diversity of aquatic plants in Lake Changhu in different years

\begin{tabular}{|c|c|c|c|c|}
\hline 年份 & 群丛名称 & $H$ & $D$ & $C / \%$ \\
\hline \multirow[t]{12}{*}{1985 年 } & 芦苇群丛 & - & - & 3.0 \\
\hline & 菰群丛 & - & - & 7.5 \\
\hline & 菰-荇菜-马来眼子菜群丛 & - & - & 6.0 \\
\hline & 荇菜-菹草 + 穗花狐尾藻群丛 & - & - & 1.5 \\
\hline & 荇菜群丛 & - & - & 2.5 \\
\hline & 菱群丛 & - & - & 7.5 \\
\hline & 紫萍群丛 & - & - & 2.5 \\
\hline & 密齿苦草群丛 & - & - & 10.0 \\
\hline & 菹草群丛 & - & - & 15.8 \\
\hline & 穗花狐尾藻群丛 & - & - & 15.0 \\
\hline & 马来眼子菜群丛 & - & - & 10.0 \\
\hline & 金鱼藻 + 轮叶黑藻群丛 & - & - & 18.8 \\
\hline \multirow[t]{14}{*}{2001 年 } & 芦苇群丛 ～～～～～ & 1.8741 & 0.5966 & 6.5 \\
\hline & 荻群丛 & 1.5616 & 0.5533 & 7.2 \\
\hline & 莲群丛 & 1.9861 & 0.6735 & 1.8 \\
\hline & 苂实-野菱 + 双角菱群丛 & 2.4562 & 0.7543 & 9.1 \\
\hline & 野菱 + 双角菱群丛 & 1.9488 & 0.6635 & 8.8 \\
\hline & 微齿眼子菜群丛 & 0.7946 & 0.2368 & 9.4 \\
\hline & 微齿眼子菜 + 竹叶眼子菜 + 狐尾藻群丛 & 1.2041 & 0.3962 & 8.4 \\
\hline & 微齿眼子菜 + 轮叶黑藻 + 大茨藻群丛 & 1.6004 & 0.5147 & 9.3 \\
\hline & 穗花狐尾藻群丛 & 1.8984 & 0.6982 & 9.5 \\
\hline & 竹叶眼子菜 + 穗花狐尾藻群丛 & 1.9862 & 0.7342 & 3.9 \\
\hline & 轮叶黑藻群丛 & 1.8906 & 0.6557 & 9.3 \\
\hline & 轮叶黑藻 + 密齿苦草 + 大茨藻群丛 & 2.1945 & 0.7437 & 8.8 \\
\hline & 密齿苦草群丛 & 1.1485 & 0.3106 & 4.9 \\
\hline & 菹草群丛 & 1.1206 & 0.3944 & 3.2 \\
\hline \multirow[t]{12}{*}{2011 年 } & 菰群丛 & 0.8515 & 0.4058 & 8.6 \\
\hline & 莲群丛 & 1.1586 & 0.5769 & 7.0 \\
\hline & 喜旱莲子草群丛 & 0.8438 & 0.4645 & 7.9 \\
\hline & 狭叶香蒲群丛 & 1.1128 & 0.6471 & 3.4 \\
\hline & 菱群丛 & 0.3865 & 0.1697 & 10.3 \\
\hline & 满江红 + 紫萍群丛 & 1.2632 & 0.6686 & 6.2 \\
\hline & 凤眼莲群丛 & 0.9768 & 0.5575 & 6.7 \\
\hline & 槐叶萍-金鱼藻群丛 & 0.8756 & 0.5386 & 10.5 \\
\hline & 密齿苦草群丛 & 0.8649 & 0.5004 & 9.1 \\
\hline & 轮叶黑藻 + 穗花狐尾藻群丛 & 1.0705 & 0.5231 & 10.8 \\
\hline & 菹草 + 金鱼藻 + 穗花狐尾藻群丛 & 0.6658 & 0.3374 & 10.4 \\
\hline & 金鱼藻 + 轮叶黑藻群丛 & 1.0095 & 0.5764 & 9.3 \\
\hline
\end{tabular}

* $H$ 为 Shannon-Wiener 多样性指数; $D$ 为 Simpson 多样性指数; $C$ 为群丛面积占全湖植被总面积的比例.

2001 年, Shannon-Wiener 多样性指数和 Simpson 多样性指数都反映了长湖水生植被群落物种多样性最 高的是苂实 - 野菱 + 双角菱群丛和轮叶黑藻 + 密齿苦草 + 大茨藻群丛, 以微齿眼子菜群丛的物种多样性最 低. 占全湖植被面积比例最大的是穗花狐尾藻群丛, 约占全湖植被总面积的 $9.5 \%$, 湖泊东部有大面积的穗 花狐尾藻, 伴生种有微齿眼子菜、竹叶眼子菜和菹草; 其次是微齿眼子菜群丛, 面积比例是 $9.4 \%$, 主要分布 于长湖的东南角; 面积比例最小的是莲群丛, 仅为 $1.8 \%$, 主要分布于湖泊中段北部的湖湾沿岸一带, 形成单 
优群落(表 2).

2011 年, 不管是 Shannon-Wiener 多样性指数还是 Simpson 多样性指数, 均以满江红 + 紫萍群丛最高, 其 次是狭叶香蒲群丛与莲群丛, 以蕰草 + 穗花狐尾藻 + 金鱼藻群丛及菱群丛的多样性指数最低. 占全湖植被 面积比例最大的群丛是轮叶黑藻 + 穗花狐尾藻群丛,约占全湖植被总面积的 $10.8 \%$, 该群落在沙洋片区河 流、湖湾均有大面积分布, 群落中常伴生有菱、金鱼藻、蕰草、马来眼子菜、浮萍等; 其次是槐叶萍一金鱼藻群 丛, 面积比例约 $10.5 \%$, 分布于长湖沙洋片湖区静水湖湾, 分布面积广大, 平均盖度可达 $90 \%$ 以上, 常见伴生 植物为轮叶黑藻、菱、穗花狐尾藻等; 比例最小的是狭叶香蒲群丛, 面积比例是 $3.4 \%$, 在沙洋区沿岸带成片 分布,伴生种有轮叶黑藻、金鱼藻、大茨藻、浮萍、槐叶萍和㭚等 (表 2).

\section{4 长湖水生植物植被覆盖率及生物量的变化}

长湖水生植被呈零星分布, 主要存在于围网之外, 网内及湖中央很少见水生植物 ${ }^{[10,14]} .1950 \mathrm{~s}$ 长湖水生 植物覆盖率接近 $100 \%{ }^{[8]}$, 但是从 1985-2011 年, 全湖水生植物覆盖率约下降了 $86.7 \%$; 全湖平均单位面积 生物量先由 $1537.5 \mathrm{~g} / \mathrm{m}^{2}$ 上升至 2001 年的 $1904.8 \mathrm{~g} / \mathrm{m}^{2}, 2006$ 年单位面积生物量 ${ }^{[15]}$ 相对于 2001 年下降了 $54.3 \mathrm{~g} / \mathrm{m}^{2}$, 但直至 2011 年, 全湖平均单位面积生物量下降到仅为 2001 年的 $1 / 10$; 全湖总生物量在 1985-2006年间稍有上升,但 2011 年全湖总生物量相比于 2006 年降低了 $88.5 \%$ (表 3).

表 3 不同时期长湖水生植物覆盖率及生物量的变化

Tab. 3 Changes of vegetation coverage and biomass of Lake Changhu in different years

\begin{tabular}{lcrrrr}
\hline 指标 & $1950 \mathrm{~s}$ & 1985 年 & 2001 年 & 2006 年 & 2011 年 \\
\hline 植被覆盖率 $/ \%$ & 100 & 90.8 & 66.5 & 30.4 & 4.2 \\
全湖平均单位面积生物量 $/\left(\mathrm{g} / \mathrm{m}^{2}\right)$ & - & 1537.5 & 1904.8 & 1850.5 & 193.5 \\
全湖总生物量 $/\left(\times 10^{4} \mathrm{t}\right)$ & - & 20.0 & 21.1 & 22.0 & 2.5 \\
\hline
\end{tabular}

\section{5 环境因子对长湖水生植物多样性的影响}

去趋势对应分析结果显示长湖物种数据 4 个轴 梯度最大值为 7.802 , 表明适合运用 CCA 分析法. 对 于环境因子来讲,排序图的第一、第二排序轴间的相 关系数均为 0 , 说明排序结果是可信的 ${ }^{[12,16]}$. 长湖物 种与环境相关性系数均为 1 ,且第一、第二序轴特征 值都很高, 说明这两序轴可以很好地解释物种数据 与环境数据所反映的大部分信息, 因而增大了此分 析结果的可信度.

由表 4 和图 2 可知,第一序轴与 TN、TP 呈极显 著的正相关, 相关系数高达 0.99 以上, 与 COD 呈负 相关;第二序轴与水深、透明度呈明显正相关, 与 $\mathrm{pH}$ 值呈负相关. 根据 8 个环境因子的影响作用, CCA 分 析将长湖采样点 10 种水生植物分为 4 个组: 种组 I

表 4 环境变量与 CCA 前两个序轴间的相关系数

Tab. 4 Weighted correlation between environment variables and the former two axes

\begin{tabular}{crr}
\hline \multirow{2}{*}{ 环境因子 } & \multicolumn{2}{c}{ 长湖 } \\
\cline { 2 - 3 } & 排序轴 1 & 排序轴 2 \\
\hline $\mathrm{D}$ & -0.4861 & 0.8391 \\
$\mathrm{SD}$ & -0.5331 & 0.8020 \\
$\mathrm{pH}$ & -0.0969 & -0.5338 \\
$\mathrm{TN}$ & 0.9945 & 0.0982 \\
$\mathrm{TP}$ & 0.9994 & 0.0264 \\
$\mathrm{COD}$ & -0.6064 & 0.7803 \\
$\mathrm{Ds}$ & -0.3903 & -0.0979 \\
Cond & -0.0981 & -0.2749 \\
\hline
\end{tabular}
包括轮叶黑藻和蕰草等水生植物, 主要分布在水深 轴附近, 与水深呈显著正相关; 种组 II 包括金鱼藻, 与透明度呈显著正相关;种组 III 主要包括菱和水鳖, 与 $\mathrm{pH}$ 值呈显著正相关; 种组 IV 有水苶和稗, 与 $\mathrm{TN}$ 、 TP 呈极显著正相关. 结果表明, TN 及 $\mathrm{TP}$ 浓度是影响长湖水 生植物分布的重要因素,而这两个环境指标综合反映了湖泊水体的富营养程度.

\section{3 讨论}

\section{1 长湖水生植被优势物种、优势群落的变化及群落演替}

与 1985 、2001 年相比,2011 年长湖水生植物在物种种类、数量及优势种上都有很大变化,其中莎草科、 苶科及眼子菜科的水生植物种类明显减少, 增加的物种是岸边的湿生植物, 如狗牙根 (Cynodon dactylon)、扛 


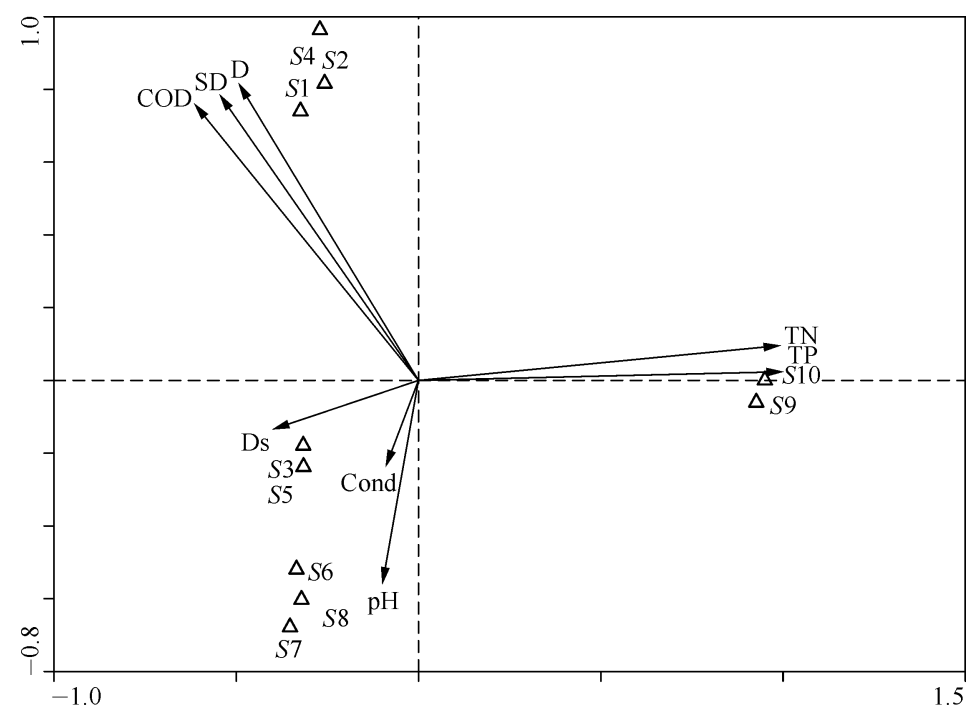

图 2 长湖水生植物物种一环境关系的 CCA 排序图 ( $\mathrm{S} 1$ : 轮叶黑藻; $\mathrm{S} 2$ : 菹草; $\mathrm{S} 3$ : 金鱼藻;

$\mathrm{S} 4$ : 浮萍; $\mathrm{S} 5$ : 槐叶萍; $\mathrm{S} 6$ : 喜旱莲子草; $\mathrm{S} 7$ : 菱; $\mathrm{S} 8$ : 水鳖; $\mathrm{S} 9$ : 水苶; $\mathrm{S} 10$ : 稗)

Fig. 2 CCA figure of species and environment of macrophytes in Lake Changhu

板归(Polygonum perfoliatum)、马齿苋( Portulaca oleracea)、车前草( Plantago asiatica) 和商陆 (Phytolacca aci$n o s a)$ 等, 这可能主要是岸带调查范围扩大所致. 增加的优势种主要有水苶、莲、菰、稗、狭叶香蒲以及外来人 侵种凤眼莲和喜早莲子草, 而在此之前占据长湖水生植物优势种地位的蓖齿眼子菜、微齿眼子菜、竹叶眼子 菜、野菱、苂实和荆三棱等现已变为伴生种或偶见种, 分布面积大大缩小. 半边莲、水车前 (Ottelia alismoides)、睡莲 (Nymphaea alba)、芦竹(Arundo donax) 等水生植物物种几乎从长湖消失, 仅在部分区域偶见. 其原因可能是近年来长湖水面大规模的围网养殖、围湖建坝、机船频繁活动、春夏高强度打草致使原本分布 面积较少、对水环境条件敏感的水生物种受到影响, 因而打破了湖区水生植被的自然演替过程, 造成部分物 种的消失 ${ }^{[15,17]}$. 但本次调查却发现了少量国家二级保护水生植物粗梗水蕨 (Ceratopteris pterioides), 可能是以 往调查没有发现或是人为引种以增加长湖水生植物多样性的原因.

1985-2011 年, 长湖水生植物群落在数量及类型上都有显著变化. 特别是漂浮植物群丛的数量由 1985 年的 1 个增加到 2011 年的 3 个, 其中包括以外来种凤眼莲为优势种的漂浮植物群落, 漂浮水生植物大量繁 殖并迅速覆盖水面, 减弱了光照强度, 不利于水生浮游动物的生长繁殖; 而浮叶植物群丛从 1985 年的 3 个减 少到 2011 年的 1 个, 主要是对水环境条件较为敏感的荇菜群丛和野菱群丛的消失; 挺水植物群丛类型在 1985-2011 年间变化也很大, 菞群丛和莲群丛依然是长湖占据优势地位的挺水植物群丛, 狭叶香蒲在近年 来增长迅速, 也成为一个单独的群丛, 外来种喜早莲子草抢占生态位, 在长湖中大量繁殖, 也形成一个群丛; 浮叶植物群丛仍然是以菱及其变种群丛为主; 沉水植物群丛数量减少 1 个, 群落结构简单化, 沉水植物种类 也变得单一。

水生植物群落的演替是一个复杂漫长的过程, 往往受到多种因素的影响, 它反映了植物与环境的动态 关系, 植物群落最明显的特征就是优势种的更替 ${ }^{[5]}$. 以群落总生物量大小作为优势群落类型划分的依据 ${ }^{[15]}$, 可以发现 30 年前和 15 年前的长湖都是以沉水植物为主要优势群落, 2006 年演替为挺水植物 + 沉水植物为 优势群落的湖泊, 直至 2011 年进一步演替为挺水植物 + 漂浮浮叶植物为优势群落的湖泊. 从时间上看, 在 1985-2011 年间, 挺水植被所占面积比例逐渐增大, 并出现了以菰、莲 + 狭叶香蒲、喜旱莲子草为优势种的 挺水植物群丛, 浮叶漂浮植被面积也在慢慢扩大, 出现以菱和浮萍 + 满江红为优势种的浮水植物群丛. 相 反, 沉水植物占植被总面积的比例虽然下降较快, 但是密齿苦草、菹草以其 $r$ 型繁殖策略和强大的地下根状 茎快速大量繁殖 ${ }^{[17-18]}$, 在长湖沉水植被中分布面积最大, 占据优势地位. 


\section{2 长湖水生植物群落演替的影响因素}

干扰包括自然干扰和人为干扰. 自然干扰一般具有偶发性,往往能在短期内丰富水生植物多样性, 如 2000 年的干旱使长湖水位大幅度下降、风浪减轻, 光照较往年显著增强, 浮水植物有了更为稳定和适宜的生 存环境,使得该种群类型在短期内迅速增加; 同样地,水位下降和光照增强快速激活沉水植物发达的地下 茎, 促进其向湖心扩展; 而挺水植物对水依赖性很强, 不能长时间忍受干旱, 所以仅局限于湖岸浅水区, 如果 水位太低还有可能导致大面积死亡 ${ }^{[19-21]}$. 过度的人为干扰往往会给湖泊水体及水生植物带来不可恢复的严 重后果, 如大力发展旅游业使得湖北武山湖水生植物多样性已彻底消失 ${ }^{[3]}$; 过度养殖和化肥投放使湖南南 湖许多水生植物灭绝 ${ }^{[22]}$; 工业生活废水大量排放使得太白湖湖水呈极度富营养化状态, 水生植被大量死亡, 藻类迅速繁殖, 水质恶化 ${ }^{[3]}$; 围网养殖和高强度打草使得安徽菜子湖逐渐由草型湖泊向藻型湖泊演替, 水生 植物多样性降低 ${ }^{[4]}$.

通常情况下, 水生植物群落多样性的丰富程度与所受干扰强度呈负相关, 而群落多样性的丧失程度与 所受干扰强度呈正相关 ${ }^{[23]}$. 此次调查也发现长湖所受干扰强度越大的区域, 消失的群丛数量、水生植物被覆 盖率和生物量就越低, 水生植物多样性丧失程度也就越严重. 长湖水生植被正在日益萎缩, 多种水生植物从 长湖消失, 还有不少种类如红菱、苂实、莲等的分布面积极大缩小, 湖水氮磷含量过高, 水体富营养化, 浮游 藻类大量繁殖, 造成水生植被覆盖率和生物量都大幅下降, 植物群落结构简单化 ${ }^{[10,13,15]}$. 从植被演替角度, 长湖现在发生的演替属于人为干扰下较剧烈的由草型湖向藻型湖的逆向演替,造成这种逆向演替的主要原 因有: (1) 在 1950s 中期至今, “以粮为纲”、“子湖群低改围”、“圈湖大战”、“精养鱼池” ${ }^{[10]}$ 等无序过度开发 项目使长湖湖中随处布满竹竿围网, 水域面积由 $433.3 \mathrm{~km}^{2}$ 缩减到 $131.1 \mathrm{~km}^{2}$, 湖水透明度由 1985 年的 $2.1 \mathrm{~m}$ 下降到 2011 年的 $0.5 \mathrm{~m}$, 多种水禽鸟类被迫迁徙,沉水植被覆盖面积和生物量锐减; (2) 富含氮磷的农业污 水、工业废水及生活污水直接排入湖中, 导致水体富营养化, 促使藻类及其它浮游类生物迅速繁殖, 水体中 溶解氧含量下降,水质恶化, 影响水生植物的生长繁殖 ${ }^{[21,24]}$. CCA 分析结果表明 TP、TN 浓度越高的水域, 即 富营养化程度越大的水域, 水生植被种类和分布越少. 实地调查及水质化验结果显示, 长湖水质处于富营养 状态的区域,水生植被覆盖率较小,水生物种种类单一,这与 CCA 分析结果一致; (3) 由于行政区划的变更, 长湖管理机构经历多次改组, 荆州与荆门两市的湖面划界始终没有解决, 渔民因在受争议水域进行作业而 发生械斗的事件常常发生. 局部养殖水域大大超过其养殖承载量极限, 致使该片水域水生植被遭到严重破 坏,甚至是灭绝 ${ }^{[25]}$,长湖现存水生植被主要集中于东部、东北部及中段沿岸 (图 1).

\section{3 长湖水生植被恢复的几点建议}

由于城市化进程速度加快, 当地政府对长湖湖区的过度开发与利用,导致湖区内及其周边的生态环境 遭到破坏,野生动物栖息地面积逐渐缩小,水生植物的生长繁殖受到阻碍, 严重影响了湖泊功能的正常发挥 和可持续发展 ${ }^{[26-28]}$. 因此, 保护和恢复长湖水生植物多样性迫在眉睫. 首先, 要降低农业面源污染, 减少上游 耕地农药化肥的施用,控制水体富营养化 ${ }^{[26]}$; 其次,要加强控制沿岸工农业废水和生活污水的大量排放,尤 其是加强点污染源的控制,对长湖两岸的企业实施严格管理,生活污水、工业废水和医疗废水等必须在处理 达标之后排放,对造成环境污染的企业要进行限期治理,实施严格的环保责任制; 第三, 要搞好湖泊疏浚,防 止底泥有机污染, 在枯水季节采用疏浚法 ${ }^{[29]}$, 将湖泊底质中富含磷、氮等营养物质的表层淤泥挖出, 运至附 近的农田、林地作为肥料, 这既可利用营养物质改良土壤, 增加农林产品的产量, 又能降低湖水中营养物质 的浓度; 第四, 要在严格控制外源污染物输人的前提下进行内源污染治理, 通过生态修复技术及人工栽种等 途径逐渐恢复受损湖泊生态系统, 提高水生植物多样性水平 ${ }^{[30]}$; 最后, 要制定相关法律法规限制大规模围网 养殖和围堤建坝, 加大对长湖的管理力度, 针对长湖湿地开展科学研究和宣传教育, 加强当地居民及旅游观 光者的环保意识,使湖泊湿地水环境处于健康稳定的状态, 最终能够长久地为人类提供各种服务功能.

\section{4 参考文献}

[1] 彭映辉, 简永兴,李仁东等. 白莲湖与西凉湖水生植物多样性的比较研究. 经济林研究, 2003, 21 (1): 18-20,

[ 2 ] 李兆华,孙大钟. 梁子湖生态环境保护研究. 北京:科学出版社,2009:58-72.

[ 3 ] 简永兴,王建波,何国庆等. 湖北省海口湖、太白湖与武山湖水生植物多样性的比较研究. 生态学报, 2001,21(11): 
$1815-1824$.

[ 4] 高 攀, 周忠泽, 马淑勇等. 浅水湖泊植被分布格局及草藻型生态系统转化过程中植物群落演替特征: 以安徽菜子 湖为例. 湖泊科学, $2011,23(1): 13-20$.

[ 5 ] 李中强,任 慧, 郝孟䂀等. 斧头湖水生植物多样性及群落演替研究. 水生生物学报,2012,36(6) :1018-1026.

[6]简永兴. 两湖平原湖泊湿地水生植物多样性编目与评价 [学位论文]. 武汉:武汉大学,2001:64-70.

[ 7 ] 金伯欣,邓兆仁,李新民. 汉江湖群综合研究. 武汉:湖北科学技术出版社, 1991:215-224.

[ 8 ] 冯 灿, 王学雷. 长湖水生维管束植物群落研究. 武汉植物学研究, 1989,7(2):123-130.

[9]彭映辉,简永兴,倪乐意等. 长湖水生植物多样性及其变化. 云南植物研究,2003,25(2):173-180.

[10］李兆华,李瑞勤. 长湖水污染防治研究. 北京:科学出版社,2009:36-44.

[11] 《中国植被》编委会. 中国植被. 北京:科学出版社,1980:16-24.

[12] ter Braak CJF. Canonical correspondence analysis: a new eigenvector technique for multivariate direct gradient analysis. Ecology, 1986,67(5):1167-1179.

[13] 彭映辉,简永兴,王建波等. 干旱对湖北省长湖水生植物多样性的影响. 水生生物学报,2003,27(2):149-154.

[14] 吴 翠,史玉虎,胡兴宜等. 浅析长湖湿地资源开发与生态保护. 湿地科学与管理,2007,3(4):38-40.

[15] 吴 翠,唐万鹏,史玉虎等. 长湖湿地水生植被演替研究. 湿地科学,2007,5(2):188-191.

[16] 孟 睿, 何连生, 过龙根等. 长江中下游草型湖泊浮游植物群落及其与环境因子的典范对应分析. 环境科学, 2013, 34 ( 7 ) :2588-2596.

[17] Grillas P. Distribution of submerged macrophytes in the Camargue in relation to environmental factors. Journal of Vegetation Science, 1990:393-402.

[18 ] Hilt S, Grose EM, Hupfer M et al. Restoration of submerged vegetation in shallow eutrophic lakes-A guideline and state of the art in Germany. Limnologica, 2006,36:107-135.

[19] Horppila J, Nurminen L. The effect of an emergent macrophyte on sediment resuspension in a shallow north temperate lake. Freshwater Biology, 2001,46:1447-1455.

[20] Sinha AK, Baruah A, Singh DK et al. Biodiversity and pollutional status in relation to physico-chemical factors of Kawar lake wetland. Journal of Freshwater Biology, 1994,6 (4) :309-316.

[21] 彭映辉,倪乐意, 简永兴等. 两湖平原六个湖泊水生植物多样性的比较研究. 云南植物研究, 2004,24(2):191-198.

[22] 简永兴,王建波,何国庆等. 洞庭湖区三个湖泊水生植物多样性的比较研究. 水生生物学报, 2001,26(2):160-167.

[23] 彭映辉,简永兴, 王建波等. 湖北省五大湖泊水生植物多样性的比较研究. 水生生物学报, 2004,28(5):464-470.

[24] 周 冰,赵文年. 长湖湿地保护与社会协调发展的思考. 湖北林业科技,2006,6:63-65.

[25] Magurran AE. Ecological diversity and its measurement. Princeton: Princeton University Press, 1988:18-32.

[26] 吴 翠,唐万鹏,史玉虎等. 长湖湿地生态价值评价. 湖北林业科技,2008,149:45-47.

[27] 彭映辉,简永兴,倪乐意. 湖北省梁子湖水生植物多样性. 中南林学院学报,2005,25(6):60-64.

[28] 彭映辉,简永兴. 鄱阳湖平原湖泊水生植物群落的多样性. 中南林学院学报,2003,23(4):22-27.

[29] 金相灿. 中国湖泊环境. 北京: 海洋出版社, 1995:65-73.

[30] 孔令阳. 江汉湖群主要湖泊生态系统健康评价——湖北省梁子湖、网湖、斧头湖、涨渡湖为例 [学位论文]. 武汉: 湖北大学, 2012:50-51. 